Primljen / Received: 27.2.2014. Ispravljen / Corrected: 23.6.2014. Prihvaćen / Accepted: 27.6.2014. Dostupno online / Available online: 10.7.2014.

\section{Ground settlement induced by tunnel boring in stiff clay}

Authors:

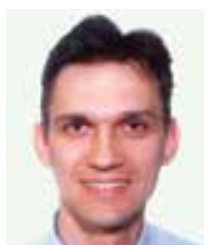

Davor Milaković, PhD. CE Institut IGH

Geotechnical Engineering

davor.milakovic@igh.hr

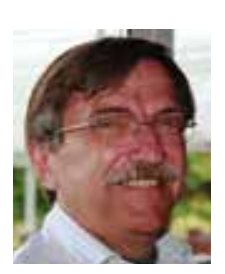

Prof. Antun Szavits-Nossan, PhD. CE

University of Zagreb

Faculty of Civil Engineer

Geotechnical Engineering

szavits@grad.hr
Original scientific paper

\section{Davor Milaković, Antun Szavits-Nossan}

\section{Ground settlement induced by tunnel boring in stiff clay}

Tunnel construction in water saturated soil causes changes in stress and strain of soil, which is primarily dependant on mechanical properties of soil in the tunnel construction zone. The paper presents a prediction of short-term and long-term deformations of soil, with a particular emphasis on ground surface settlements after the tunnel construction. The aforementioned predictions were made using a widely applicable numerical soil model that accurately describes the results of triaxial tests, in combination with the existing procedures for determination of soil parameters, taking at that into account natural heterogeneity of the soil as observed through heterogeneity of natural moisture of clay.

Key words:
tunnel, settlements, 3D model, heterogeneity, stiff clay

Davor Milaković, Antun Szavits-Nossan

Izvorni znanstveni rad

\section{Slijeganja tla izazvana bušenjem tunela u krutim glinama}

Izvođenje tunela u vodom zasićenom tlu izaziva u tlu promjene naprezanja i deformacija koje prije svega ovise o mehaničkim karakteristikama tla u zoni izgradnje tunela. U ovom radu su prognozirane kratkotrajne i dugotrajne deformacije tla te naročito slijeganja na površini terena nakon izvedbe tunela. Navedene prognoze su dobivene pomoću široko primjenjivanog numeričkog modela tla koji vjerno opisuje rezultate troosnih ispitivanja, uz primjenu postojećih postupaka određivanja parametara tla, ali uzimajući u obzir njegovu prirodnu heterogenost uočljivu kroz heterogenost prirodne vlažnosti gline.

KIjučne riječi:

tunel, slijeganja, 3D model, heterogenost, krute gline

Wissenschaftlicher Originalbeitrag

Davor Milaković, Antun Szavits-Nossan

\section{Durch Tunnelbohrungen verursachte Bodensetzungen steifer Tonböden}

Die Tunnelkonstruktion in wassergesättigtem Boden verursacht Veränderungen des Spannungs- und Dehnungszustandes, der hauptsächlich von den mechanischen Bodeneigenschaften in der Konstruktionszone abhängt. In dieser Arbeit werden Kurzzeitund Langzeitverformungen des Bodens, insbesondere Setzungen der Erdoberfläche, nach der Tunnelkonstruktion bestimmt. Die Vorhersage der Verformungen beruht auf weit angewandten numerischen Bodenmodellen, die zusammen mit bestehenden Verfahren für die Bestimmung von Bodenparametern Resultate triaxialer Versuche mit Genauigkeit beschreiben, und die aufgrund der uneinheitlichen Feuchtigkeit erkennbare natürliche Bodenheterogenität berücksichtigen.

Schlüsselwörter:

Tunnel, Setzung, 3D Modell, Heterogenität, steife Tonböden 


\section{Introduction}

Possibilities for building a metro system, and ways in which such a system should be built, have been considered in the city of Zagreb for quite a long time. The terrain in the central part of Zagreb is characterized by stratified water saturated soil in which gravel formations, topped with thinner layers of clay and fill material, are found down to some ten meters in depth. In greater depths, soil is formed of heavily overconsolidated stiff clay formations. It is precisely these stiff clays that are favourable for construction of tunnel tubes for the metro system. However as buildings built in the period between the two world wars, and even earlier, are dominant in the central part of Zagreb, and as they are structurally highly sensitive to total and differential settlements, it is very significant to investigate the effect the tunnel construction in stiff clay would have on the immediate and consolidation settlements of the ground surface.

The prediction of ground surface settlements caused by geotechnical activities, even those that are very simple in character, is regarded to be of limited accuracy for a number of reasons. It is generally considered that these reasons include soil nature (heterogeneity caused by complex geological processes), limitations as to scope, type and quality of testing of its mechanical properties, limitations relating to available behaviour models, and many details relating to construction technology that can not accurately be covered by analytical procedures using means and processes that are currently at our disposal [1-3].

In standard geotechnical activities (soil settlement, bearing capacity of piles, etc.), prediction procedures are often based, because of the above mentioned problems, on the establishment of correlations between appropriate soil testing results and measured displacements on the existing structures, as obtained through back analyses. Such correlations are likely to provide a more reliable estimate of soil displacements, than those based on laboratory soil testing and use of mechanical theories. However, these correlations can only be established for those standard structures that have already been tested in great numbers and in different types of soil.

The extent and rate of soil settlement caused by deep tunnel boring activity is a complex problem in soil mechanics. Not many such undertakings have so far been realized, and there are even less of those with the quantity of soil testing results and displacement measurements that would be sufficient to enable establishment of correlations between the soil testing and displacement. This is why the profession can presently only rely on laboratory testing of mechanical properties of representative soil samples, on appropriate in-situ soil testing, and on the use of mechanical models for defining behaviour of geotechnical structures (finiteelement method, etc.). As there is very little experience on the use of such procedures for investigating the influence of tunnel boring on displacements at the ground surface, the verification of such procedures in cases where the soil has relatively well been tested, and where measured data on displacements and pore pressures exist, can be professionally highly interesting and rewarding. One of rare published cases of this type, and certainly the most interesting one by its extent and quality, is the tunnel construction along the JLE metro line in London. This can be of particular interest to our professional community as in this case the soil is mostly formed of highly overconsolidated stiff clay, which is in many aspects quite similar to the clay found at the depths of more than $10 \mathrm{~m}$ in the city of Zagreb. Mechanical properties of the London clay formations traversed by these tunnels are very good and they had been thoroughly tested during realisation of the project. Tunnels were excavated using special tunnel boring machines that provide rotary mechanical shieldsupported boring thrust at the front, with simultaneous erection of precast concrete lining immediately behind the boring machine. The program involving very extensive settlement measurements on the surface, soil deformation measurements along the depth, and measurements of ground water pressure variations caused by drilling, was implemented at the St. James's Park site in London in regular time intervals throughout realization of the tunnelling work.

So far the most detailed study of these data is the one conducted by Wongsaroj et al. [4,5]. Their analyses are based on extensive triaxial and oedometer laboratory testing of clay from goodquality undisturbed samples obtained during investigations at various localities in London, and also on various in-situ investigations of soil (geological and geophysical surveys, insitu permeability testing, etc.). The authors paid a particular attention to the influence of the initial state of stress and to the influence of soil stiffness anisotropy. They demonstrated that the stiffness anisotropy, with horizontal stiffness of London clay being up to $50 \%$ greater that the vertical one, exerts a significant influence on the extent of soil settlement. In their analyses, they used and adjusted to their needs a complex nonlinear elastoplastic constitutive soil model proposed by Hashiguci and Uen [6], which takes into account the effect of the initial state of stress, anisotropy, direction of stress change, and the soil strength mobilisation level. It is significant that they determined the decisive drainage influence the tunnel lining installation exerts over time on the extent and development of deformations in the soil and on the surface. All things considered, Wongsaroj and his associates have shown with their analyses that detailed investigation works reveal significant mechanical properties of stiff clays and that these properties, once incorporated in an appropriate soil behaviour model - and taking into account adequate boundary conditions of drainage in tunnel lining and boundary conditions caused by successive tunnel boring activity - provide a technically acceptable prediction of the immediate and consolidation settlement of the ground surface.

Nevertheless, Wongsaroj and his associates neglect in their investigations some available data which show that the London clay layer contains sub-layers presenting various mechanical properties, primarily with regard to natural moisture [7-9]. The difference in mechanical properties along the height of this thick clay layer is not surprising considering the age and complex geological history of formation of this clay, which is 
hardly adequate for forming an ideally homogenous soil layer. That is why this kind of heterogeneity can also be expected in thicker clay layers where, due to the time of their formation, the geological past is highly complex. As it is generally known that the stiffness of clays of similar mineralogical composition is greatly influenced by their moisture content (along with the immediate state of stress), it can reasonably be assumed that the change in moisture will influence their stiffness, if all other parameters remain the same. Numerous published triaxial tests, conducted on undisturbed samples for various depths of London clay layers, enable examination of the hypothesis on the influence of moisture on stiffness of the London clay and, if it is determined that such influence exists, the influence of heterogeneity of London clay on soil settlement due to tunnel boring can also be examined.

A drawback of complex analyses made by Wongsaroj and his associates is the mathematical model that was used to study clay behaviour. The use of the model was restricted to a narrow circle of researchers, and its parameters do not have a clear physical meaning, which is why relatively obscure procedures are needed for their determination. This is not a negligible problem as to the practical use of such model, because an inadequate selection of parameters for the model, as one of key steps in numerical simulations, may make the model nontransparent and subjective. This is why two appropriate questions may be put: first, what is the influence of this inhomogeneous distribution of London clay mechanical properties along the depth, and second, is it really necessary to use a little known complex soil-behaviour model, and very non-standard and not readily accessible tests for the determination of soil anisotropy, to obtain a practically acceptable prognosis of soil settlement for a complex case of tunnel pipe construction in the underground?

This paper attempts to provide answers to these questions and in this respect, it provides a numerical simulation of the tunnel in London and of the foundation pit excavation in Zagreb, taking at that into account standardly available tests for determining spatial heterogeneity of mechanical properties of soil, and using a commercially available and a relatively widely applied analytical tool (finite-element method and an isotropic nonlinear elastoplastic soil behaviour model whose parameters have a clear physical meaning).

\section{Selected soil model}

The isotropic double strengthening elastoplastic 'Hardening soil" model (HS model) was used in this paper for analysing the case of tunnel construction in London and the case of foundation pit excavation in Zagreb. This model has a potential for describing complex stress and strain relationships in soil [10-12] and it has been widely applied internationally and in our country. This constitutive soil model for determination of material parameters uses results as obtained by normal laboratory and in-situ testing. The usability of this model in case of stiff clays, which are the focus of study in this paper, was verified by comparing results obtained by model simulations of triaxial and oedometer tests, with results of similar tests obtained in laboratory, for various locations in London and Zagreb.

The simulation of triaxial consolidation test under drained conditions (CD/CID/DC), and simulation of one-dimensional consolidation in oedometer (E/OED/O), were conducted in the first step. Laboratory test results for London clay from the location of new Terminal 5 of the Heathrow Airport in London were used for these simulations [13]. Laboratory test results were entered into constitutive equations of the HS model and, in this way, computation parameters corresponding to the chosen soil sampling depths were obtained. Standard soli behaviour curves were obtained using the SoilTest program, which numerically simulates laboratory tests. These curves were then compared with original laboratory test results [14]. The comparison of laboratory drained test results and model results is presented in Figure 1.

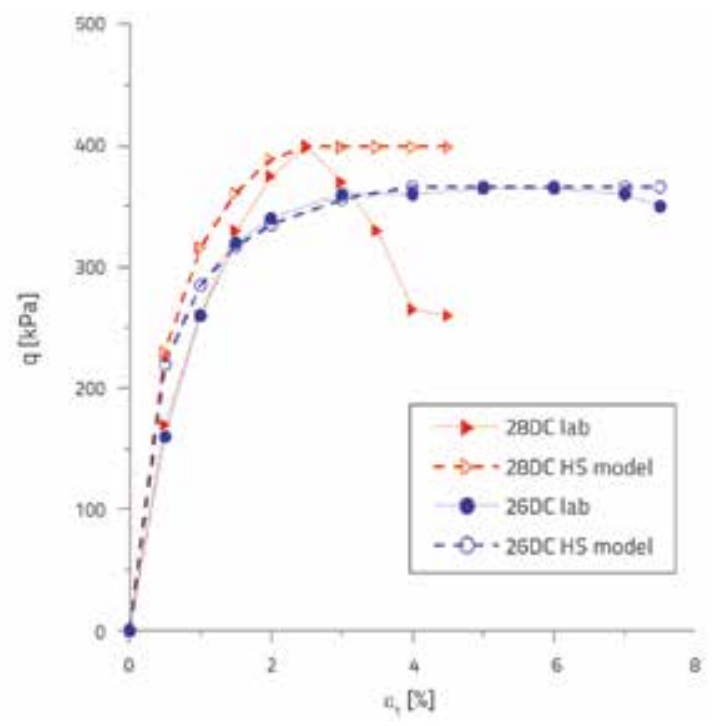

Figure 1. HS model simulation of triaxial drained tests of London clay, $\varepsilon_{1}$-q curve

Numerical simulation results show a good correspondence between the $\varepsilon_{1}-q$ curves and laboratory test results. The value of deviator stress at failure $q=\sigma_{1}{ }^{\prime}-\sigma_{3}{ }^{\prime}$ is dominantly influenced by the angle of internal friction, $\varphi^{\prime}$, and cohesion, $c^{\prime}$. The shape of curve $\varepsilon_{1}-q$ of the laboratory testing marked 28DC, which is otherwise typical for the London overconsolidated clay, shows a softening behaviour once the peak strength $q_{\max }$ is attained. As the Hardening Soil Model does not recognise soil softening, the simulation of deviator stress after failure stays at the same level, unlike the laboratory test curve which drops to the level of residual stress. The comparison of oedometer test results obtained in laboratory and on the model is shown in Figure 2. It can generally be stated that numerical simulation results imitate well primary settlement curves obtained in laboratory. Greater deviations can however be observed at relaxation during greater stress values. 
a)

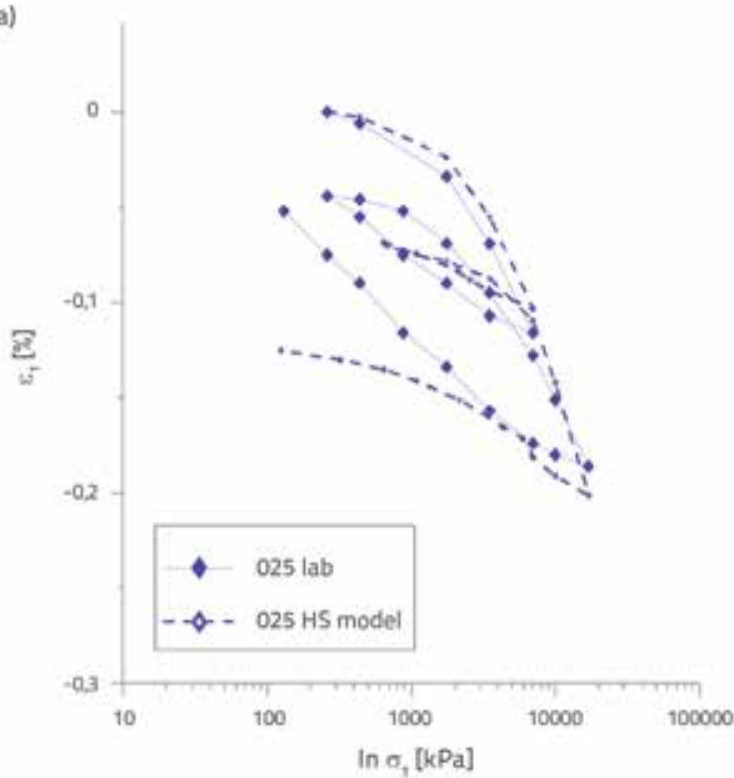

b)

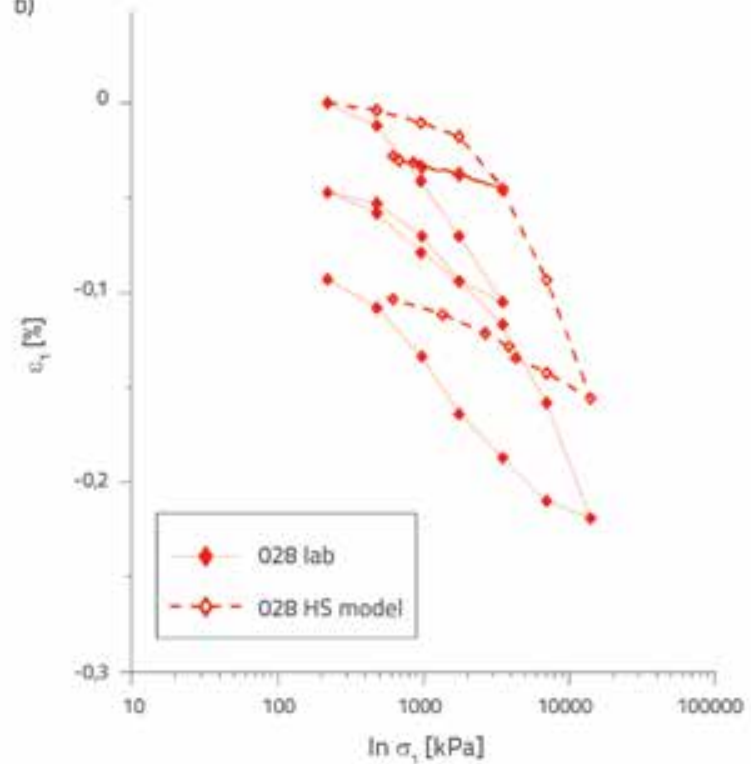

Figure 2. Simulation of oedometer tests for London clay in HS model: a) 025 ; b) 028
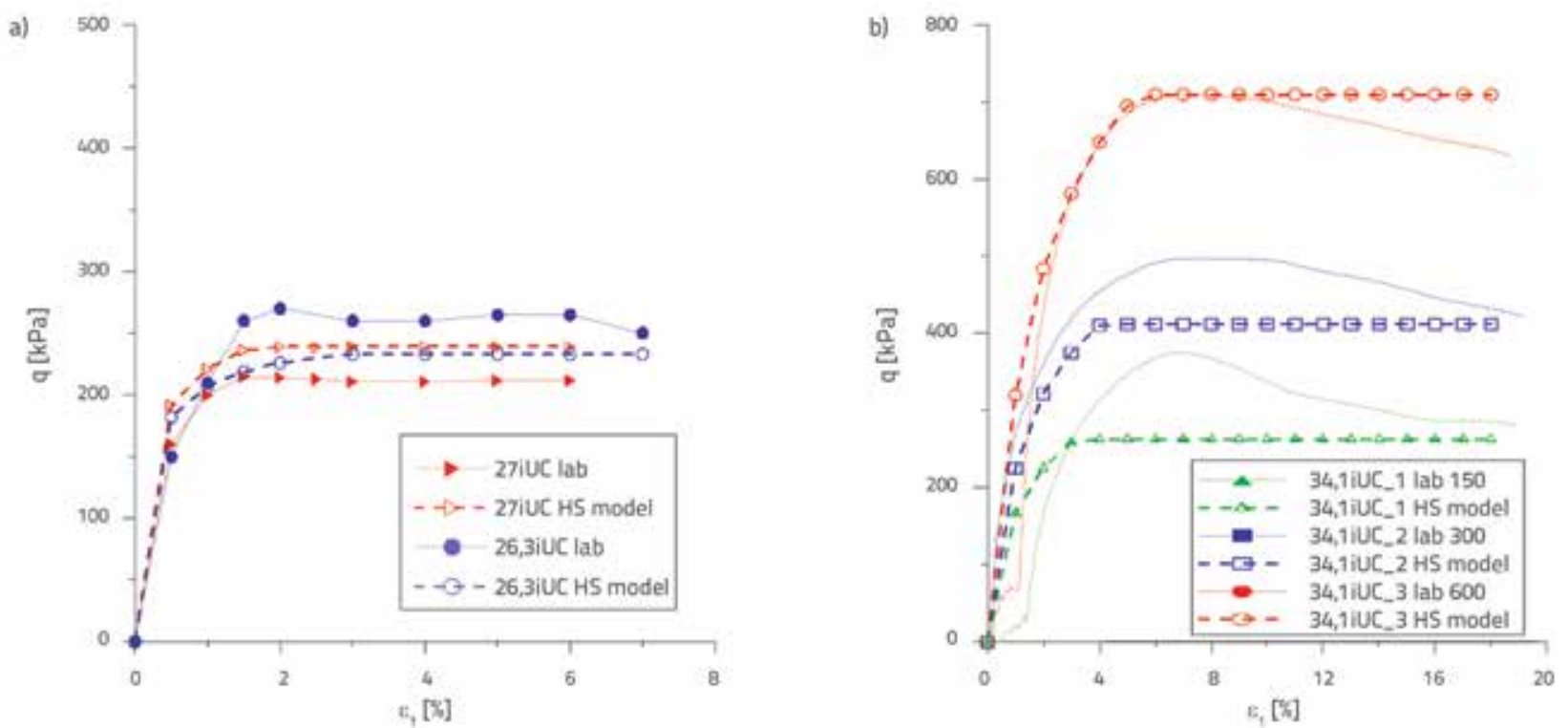

Figure 3. Simulation of triaxial undrained tests for London and Zagreb clays in HS model: a) $\varepsilon_{1}$-q curve for London clay; b) $\varepsilon_{1}$-q curve for Zagreb clay

The second step comprised verification of previously selected computation parameters using the Hardening Soil Model through which the standard consolidation triaxial testing in undrained conditions (CU/CIU/UC) was simulated. As samples were taken from the same London clay sub-layers, the computed effective Hardening Soil Model parameters were similar to those used for the triaxial drained testing.

Comparative results for the consolidation triaxial undrained testing in laboratory and on the model show a good correspondence for both test samples (Figure 3.a).

The simulation of undrained tests for Zagreb clay at the Ban Centre locality in Zagreb was made to gain a better insight into the behaviour of stiff clays in undrained conditions. The comparison of laboratory testing and model results is shown in Figure 3.b.

Comparative analyses of $\left(\varepsilon_{1}-q\right)$ curves mostly confirm the analyses conducted on London clay. $\varepsilon_{1}$-qcurves of all laboratory tests of Zagreb clay show a certain softening behaviour once the peak strength $q_{\text {max }}$ is achieved, but it is much lower when compared to standard curves $(\varepsilon-q)$ obtained for London clay (test 28DC in Figure 1). The reason for this behaviour trend probably lies in a lower overconsolidation of Zagreb clay.

It can be concluded from comparative analysis of curves that the HS model adequately describes triaxial and oedometer test results for stiff clays. 


\section{Heterogeneity of clay and selected soil model parameters}

The heterogeneity of thick London clay formations is inter alia manifested in heterogeneous distribution of natural moisture as related to the depth below the ground surface. The analysis of this distribution and other available data enabled researchers to distinguish between several clay sub-layers, each with approximately linear distribution of natural moisture values along the sub-layer depth [7-9]. Based on available triaxial tests of undisturbed clay samples extracted from $\mathrm{T} 5$ sites at Heathrow Airport and the Kennington site in the centre of London $[13,15]$, Milakovic [14] determined the HS model parameters, separately for each test. He then established a linear correlation between thus obtained parameters and natural moisture of undisturbed soli samples within each of the previously selected sub-layers. He used parameters of these liner correlations to determine the distribution of HS model parameters along the depth below the
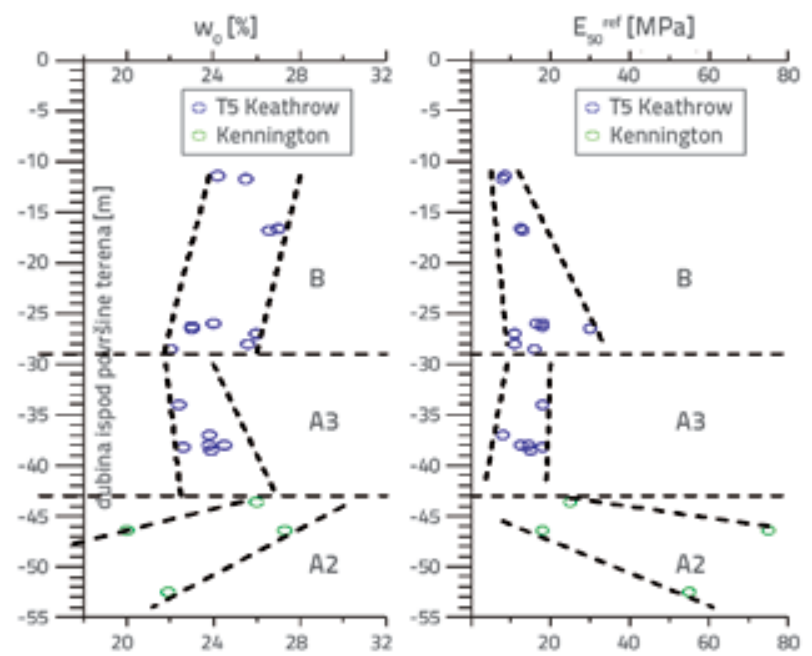

Figure 4. Distribution of measured stiffness moduli, $E_{50}{ }^{\text {ref }}$ along the depth and the corresponding natural moistures, $w_{0}$ obtained from London clay samples on localities T5 of Heathrow Airport [13] and Kennington [15] ground surface for each of sub-layers from the St James Park site, for which comparisons will be made between numerical simulation of metro construction at the JLE line and site measurements during actual construction of these tunnels. The procedure for determining the HS model parameters will be presented in the paper for the parameter $E_{50}$ ref only. This is the stiffness parameter that links the Young's secant modulus $E_{50}$ (when the deviator stress attains $50 \%$ of soil strength) with the smaller main effective stress in soil, $\sigma_{3^{\prime}}^{\prime}$ according to the following expression:

$E_{50}=E_{50}^{\text {ref }}\left(\sigma_{3}^{\prime} / p_{\text {ref }}\right)^{m}$

where $p_{\text {ref }}=100 \mathrm{kPa}$, while $m$ is the parameter regulating dependence between the stiffness and the state of stress. The results of this procedure are shown in Figures 4, 5, 6, and 7. Figure 4 shows the distribution between the natural moisture $W_{0}$ and the $E_{50}$ ref parameter along the depth for triaxial tests conducted in sub-layers $A 2, A 3$ and $B$ at the
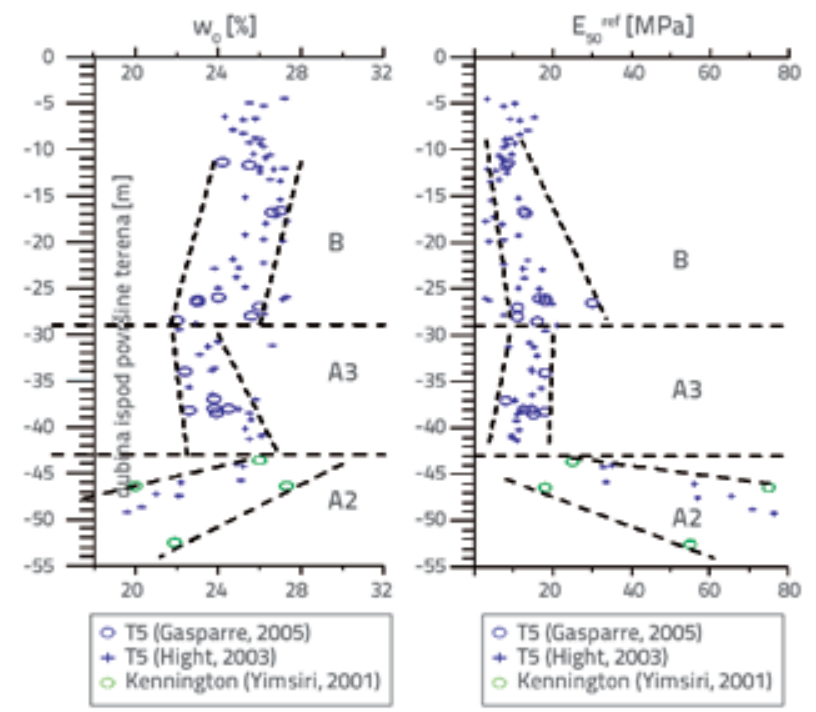

Figure 6. Comparison of measured values $E_{50}{ }^{\text {ref }}$ (circles) and predicted values $E_{50}$ ref (crosses) obtained from correlations $E_{50}$ ref and natural moisture $w_{0}$ at the locality T5 on the Heathrow Airport [9]
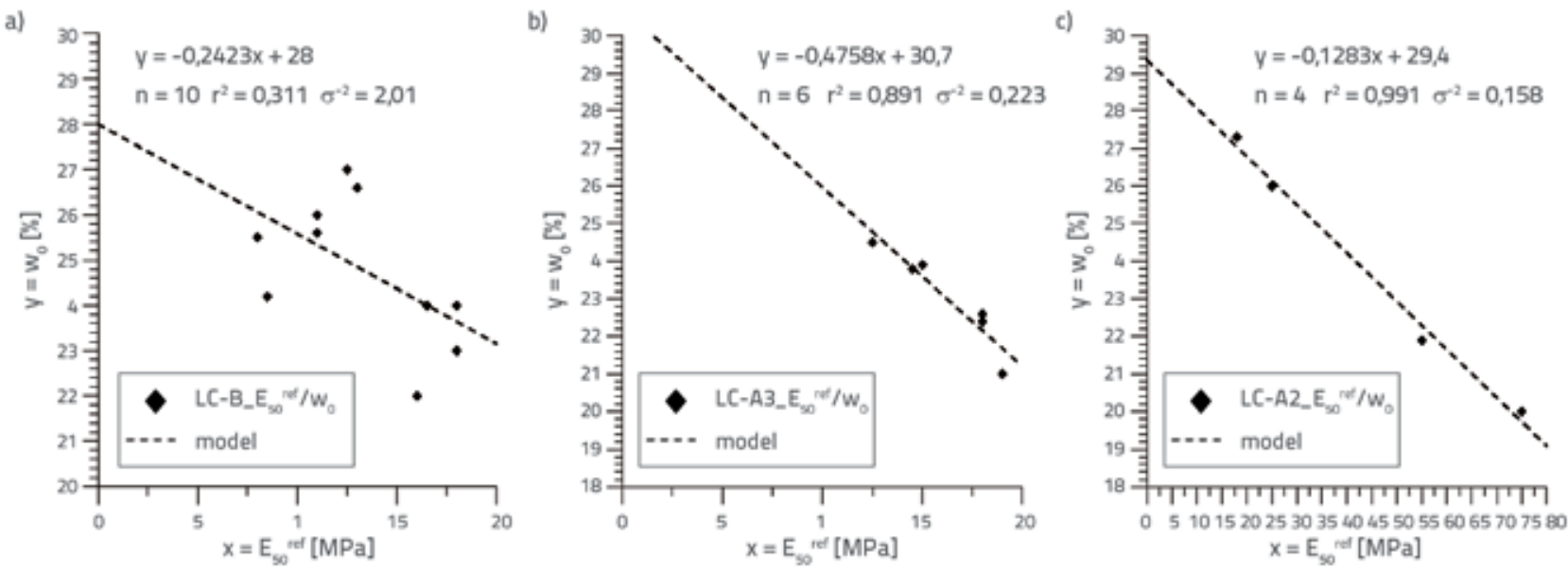

Figure 5. Local correlation $E_{50}$ ref and $w_{0}$ : a) for London clay sub-layer $\mathrm{B} ; \mathrm{b}$ ) for London clay sub-layer $\mathrm{A} 3$; c) for London clay sub-layer $\mathrm{A} 2$ 
localities T5 of Heathrow Airport [13] and Kennington [15]. Figure 5 shows local linear correlations between the natural moisture and stiffness parameters within sub-layers from Figure 4. Figure 6 shows the application of correlations from Figure 5 to all moisture data on localities T5 of Heathrow Airport and Kennington, while Figure 7 shows the application of these correlations to available natural moistures data at the locality of St. James Park. Similar results were also obtained by applying this procedure to other HS model parameters [14].
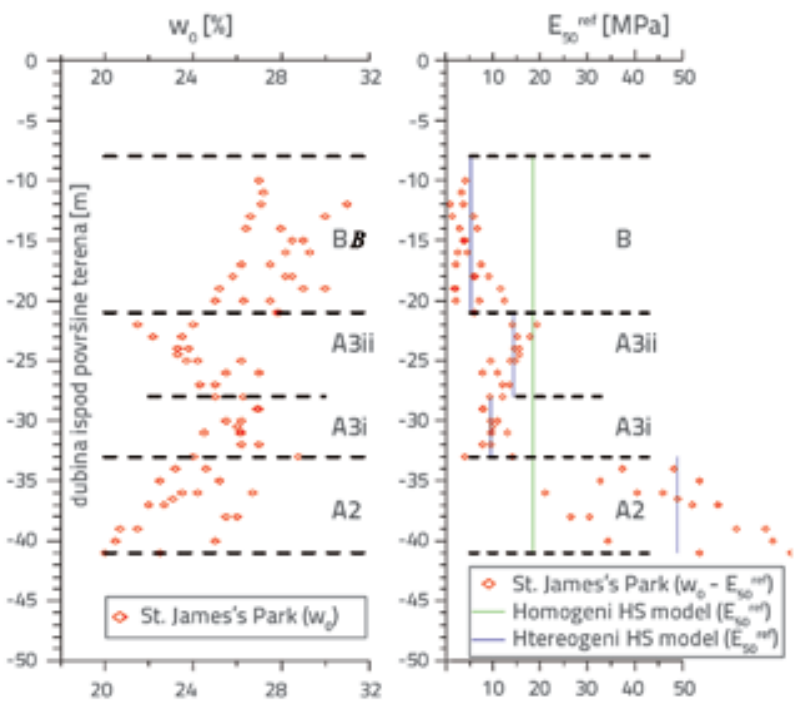

Figure 7. Determination of calculated stiffness moduli, $E_{50}$ ref from the homogeneous and heterogeneous HS model based on correlations with the measured natural moisture at St James's Park [16]

\section{Confirmation of acceptability of proposed procedures and numerical soil model}

The acceptability of procedures for determination of numerical soil model parameters was confirmed through comparison of numerical simulation results for the case of tunnel construction at St. James's Park in London, and simulation of the foundation pit excavation at Ban Centre in Zagreb, with measurement

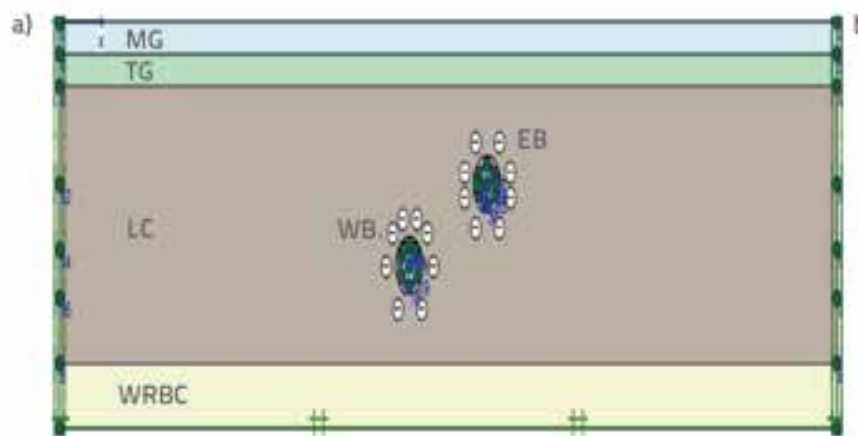

results obtained during construction of these tunnels and the mentioned foundation pit.

\subsection{Numerical simulation of measured tunnel excavation in London clay}

The analysis of tunnel construction at the locality of St. James's Park in London was conducted for two HS models: one that takes into account the heterogeneity of soil (Figure 8.b), where material parameters of London clay are defined for each of the geological sub-layers, and the other that treats the London clay as a homogeneous soil (Figure 8.a), where material parameters were obtained as an average value of parameters of all geological sub-layers of London clay. In addition to the HS model, the results of Wongsaroj study [4] on isotropic and anisotropic models were also compared, whenever possible. Deviations between the calculated and measured values are presented in Figure 9. Cross shown in smaller figure marks the tunnel tube position as related to the bench mark on the ground surface, marked with triangle. Deviations between the calculated and measured settlements, as given in Figure 9, can be presented by means of the following equations at some typical moments (T1 to T4) during the progress of tunnel construction:

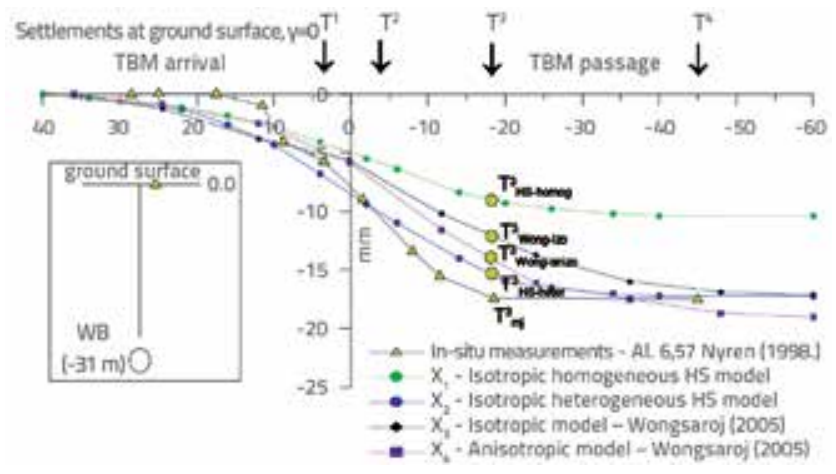

Figure 9. Procedure for determining deviations between the calculated and measured settlements during construction of the west-side tunnel tube at the St James Park locality

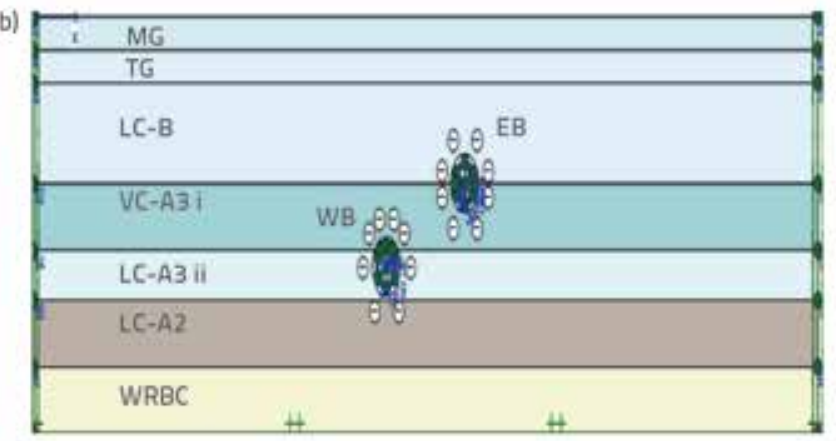

Figure 8. Schematic view of: a) homogeneous; b) heterogeneous HS model at the St. James's Park locality in London (WB - west-side tunnel tube, EB - east-side tunnel tube, MG - embankment, TG - gravel, LC - London clay, WRBC - WRB clay in the substratum) 
Homogeneous HS model, expression (2)

$$
X_{1}=\frac{1}{4}\left[\frac{\mid y\left(T_{m j}^{1}\right)-y\left(T_{H S \text {-homog }}^{1} \mid\right.}{y\left(T_{m j}^{1}\right)}+\frac{\mid y\left(T_{m j}^{2}\right)-y\left(T_{H S \text {-homog }}^{2} \mid\right.}{y\left(T_{m j}^{2}\right)}+\frac{\mid y\left(T_{m j}^{3}\right)-y\left(T_{H S \text {-hom } g}^{3} \mid\right.}{y\left(T_{m j}^{3}\right)}+\frac{\mid y\left(T_{m j}^{4}\right)-y\left(T_{H S \text {-homg }}^{4}\right)}{y\left(T_{m j}^{4}\right)}\right]
$$

Heterogeneous HS model, expression (3)

$$
X_{2}=\frac{1}{4}\left[\frac{\mid y\left(T_{m j}^{1}\right)-y\left(T_{H S-\text { hetert }}^{1}\right)}{y\left(T_{m j}^{1}\right)}+\frac{\mid y\left(T_{m j}^{2}\right)-y\left(T_{H S-\text { hetert }}^{2}\right)}{y\left(T_{m j}^{2}\right)}+\frac{\mid y\left(T_{m j}^{3}\right)-y\left(T_{H S-\text { heter }}^{3}\right)}{y\left(T_{m j}^{3}\right)}+\frac{\mid y\left(T_{m j}^{4}\right)-y\left(T_{H S-\text { heter }}^{4}\right)}{y\left(T_{m j}^{4}\right)}\right]
$$

Isotropic Wongsaroj model, expression (4)

$$
X_{3}=\frac{1}{4}\left[\frac{\mid y\left(T_{m j}^{1}\right)-y\left(T_{W o n g i z o}^{1}\right)}{y\left(T_{m j}^{1}\right)}+\frac{\mid y\left(T_{m j}^{2}\right)-\left(T_{W o n g i z o}^{2}\right)}{y\left(T_{m j}^{2}\right)}+\frac{\mid y\left(T_{m j}^{3}\right)-y\left(T_{W o n g i z o}^{3} \mid\right.}{y\left(T_{m j}^{3}\right)}+\frac{\mid y\left(T_{m j}^{4}\right)-y\left(T_{W o n g}^{4} i=o\right.}{4} \mid\right]
$$

Anisotropic Wongsaroj model, expression (5)

$$
X_{4}=\frac{1}{4}\left[\frac{y\left(T_{m j}^{1}\right)-y\left(T_{\text {Wonganizod }}^{1}\right.}{y\left(T_{m j}^{1}\right)}+\frac{\mid y\left(T_{m j}^{2}\right)-y\left(T_{\text {Wonganizod }}^{2}\right)}{y\left(T_{m j}^{2}\right)}+\frac{\mid y\left(T_{m j}^{3}\right)-y\left(T_{\text {Wonganiod }}^{3}\right)}{y\left(T_{m j}^{3}\right)}+\frac{\mid y\left(T_{m j}^{4}\right)-\left(T_{\text {Wonganiod }}^{4}\right)}{y\left(T_{m j}^{4}\right)}\right]
$$

where

$y\left(T_{i m j}\right)$ - is the measured soil settlement value at the moment of TBM passage through the position "i",

$y\left(T_{i H S}\right) \quad$ - is the calculated soil settlement value at the moment of TBM passage through the position "i" (HS model),

$y\left(T_{\text {iwong }}\right)$ - is the calculated soil settlement value at the moment of TBM passage through the position "i" (Wongsaroj model).
Comparisons were made for the following numerical models: HS model (homogeneous and heterogeneous), and for the Wongsaroj model (isotropic and anisotropic), whenever possible. In fact, in his study Wongsaroj [4] did not show the isotropic and anisotropic model results for all cases that are analysed in this paper.

Deviations of calculation results from field measurements, as obtained by Nyren [17], are shown in Table 1.

It can be seen from average deviation results given in Table 1 that the $\mathrm{HS}$ model, which takes into account the natural heterogeneity of soil, shows much smaller deviations (27\%) as related to the HS model that treats London clay as a homogeneous soil $(40$ $\%)$. This especially concerns settlements on the ground surface.

Furthermore, it was observed that the heterogeneous HS model better

\begin{tabular}{|c|c|c|c|c|c|c|}
\hline \multirow{2}{*}{ 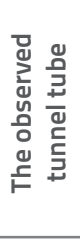 } & $\begin{array}{l}\text { Numerical simulation } \\
\text { of tunnel boring at St. } \\
\text { James's Park in London }\end{array}$ & $\begin{array}{l}\text { Isotropic } \\
\text { homoge- } \\
\text { neous HS } \\
\text { model }\end{array}$ & $\begin{array}{l}\text { Isotropic } \\
\text { heteroge- } \\
\text { neous HS } \\
\text { model }\end{array}$ & $\begin{array}{l}\text { Wongsaroj } \\
\text { isotropic } \\
\text { model }\end{array}$ & $\begin{array}{l}\text { Wongsaroj } \\
\text { anisotropic } \\
\text { model }\end{array}$ & \multirow{2}{*}{$\begin{array}{l}\text { Calculation alternatives } \\
\text { - at ground surface } \\
\text { - at the certain depth of y } \\
\text { - longitudinal to tunnel axis } \\
\text { - transverse to tunnel axis }\end{array}$} \\
\hline & \multicolumn{5}{|c|}{$\begin{array}{l}\text { [\%] Mean deviations of calcuations from field measurements, according to Nyren } \\
{\left[[17]^{*}\right.}\end{array}$} & \\
\hline \multirow{6}{*}{ 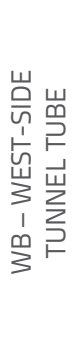 } & \multirow{5}{*}{$\begin{array}{l}\text { Immediate soil } \\
\text { settlements }\end{array}$} & 37 & 5 & 20 & 17 & At ground surface $y=0$ longitudinal to tunnel axis \\
\hline & & 39 & 11 & 20 & 15 & At the depth of $y=-9,4 \mathrm{~m}$ longitudinal to tunnel axis \\
\hline & & 32 & 17 & 19 & 21 & At the depth of $y=-22,6 \mathrm{~m}$ longitudinal to tunnel axis \\
\hline & & 8 & 37 & 42 & 24 & At the depth of $y=-27,5 \mathrm{~m}$ longitudinal to tunnel axis \\
\hline & & 32 & 31 & 44 & 39 & At ground surface $y=0$ transverse to tunnel axis \\
\hline & $\begin{array}{l}\text { Immediate horizontal } \\
\text { displacements }\end{array}$ & 36 & 18 & 20 & 17 & $4 \mathrm{~m}$ to the right of the tunnel axis \\
\hline \multirow{5}{*}{ 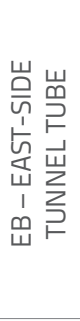 } & \multirow{4}{*}{$\begin{array}{l}\text { Immediate soil } \\
\text { settlements }\end{array}$} & 51 & 38 & - & 30 & At ground surface $y=0$ longitudinal to tunnel axis \\
\hline & & 58 & 33 & - & 25 & At the depth of $y=-9,0 \mathrm{~m}$ longitudinal to tunnel axis \\
\hline & & 57 & 33 & - & 32 & At the depth of $y=-12,4 \mathrm{~m}$ longitudinal to tunnel axis \\
\hline & & 47 & 38 & - & 17 & At ground surface $y=0$ transverse to tunnel axis \\
\hline & $\begin{array}{l}\text { Immediate horizontal } \\
\text { displacements }\end{array}$ & 47 & 54 & - & 31 & $4 \mathrm{~m}$ to the right of the tunnel axis \\
\hline \multirow{2}{*}{$\begin{array}{l}\mathscr{m} \\
\stackrel{+}{+} \\
\stackrel{m}{3}\end{array}$} & \multirow{2}{*}{$\begin{array}{l}\text { Deviation of immediate } \\
\text { soil settlements }\end{array}$} & 40 & 27 & - & 24 & AVERAGE \\
\hline & & 58 & 54 & 44 & 39 & MAXIMUM \\
\hline
\end{tabular}
describes immediate settlements for the case of tunnel situated in deeper

Table 1. Results of numerical simulations and on-site observations: comparison of immediate settlements of soil 
Table 2. Results of numerical simulations and field observations: comparison of consolidation settlements of soil

\begin{tabular}{|c|c|c|c|c|c|c|}
\hline \multirow{2}{*}{ 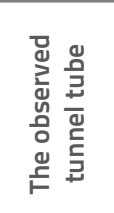 } & $\begin{array}{c}\text { Numerical simulation } \\
\text { of tunnel boring at } \\
\text { St. James's Park in } \\
\text { London }\end{array}$ & $\begin{array}{l}\text { Isotropic } \\
\text { homoge- } \\
\text { neous HS } \\
\text { model }\end{array}$ & $\begin{array}{l}\text { Isotropic } \\
\text { heteroge- } \\
\text { neous HS } \\
\text { model }\end{array}$ & $\begin{array}{l}\text { Wongsaroj } \\
\text { isotropic } \\
\text { model }\end{array}$ & $\begin{array}{c}\text { Wongsaroj } \\
\text { anisotropic } \\
\text { model }\end{array}$ & \multirow{2}{*}{$\begin{array}{l}\text { Calculation alternatives } \\
\text { - at ground surface } \\
\text { - at the certain depth of y } \\
\text { - longitudinal to tunnel axis } \\
\text { - transverse to tunnel axis }\end{array}$} \\
\hline & \multicolumn{5}{|c|}{ [\%] Mean deviations of calcuations from field measurements, according to Nyren [17]* } & \\
\hline \multirow{2}{*}{ 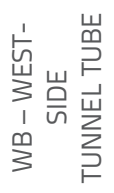 } & \multirow{2}{*}{$\begin{array}{l}\text { Consolidation } \\
\text { settlement of soil }\end{array}$} & 29 & 22 & - & 32 & $\begin{array}{l}\text { At the ground surface } y=0 \\
\text { transverse to the tunnel axis }\end{array}$ \\
\hline & & 12 & 16 & - & 21 & At the depth of $y=-5,5 m$ \\
\hline \multirow{2}{*}{ 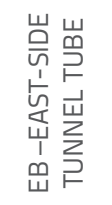 } & \multirow{2}{*}{$\begin{array}{l}\text { Consolidation } \\
\text { settlement of soil }\end{array}$} & 52 & 3 & - & - & $\begin{array}{l}\text { At the ground surface } y=0 \\
\text { transverse to the tunnel axis }\end{array}$ \\
\hline & & & 25 & - & - & At the depth of $y=-5,0 m$ \\
\hline \multirow{2}{*}{$\begin{array}{l}m \\
w \\
+ \\
m \\
⿱ 亠 䒑\end{array}$} & \multirow{2}{*}{$\begin{array}{l}\text { Deviation of } \\
\text { consolidation } \\
\text { settlement of soil }\end{array}$} & 27 & 17 & - & 26 & AVERAGE \\
\hline & & 52 & 25 & - & 32 & MAXIMUM \\
\hline
\end{tabular}

clay layers, while the Wongsaroj's anisotropic model describes more favourably immediate soil settlements for the case of tunnel situated closer to the ground surface. Generally, the comparison of deviations of these two models as related to field measurements reveals that predictions of immediate soil settlements obtained by the heterogeneous HS model are, on average, no worse that those obtained by the much more complex Wongsaroj model which takes into account the London clay stiffness anisotropy.

A similar procedure was used to obtain deviations between calculated and measured consolidation settlements of soil for the west-side and east-side tunnel tubes. Deviation results calculated with respect to in-situ measurements by Nyren [17] are presented in Table 2.

It can be seen from average deviation results shown in Table 2 that the HS model which takes into account the natural heterogeneity of soil shows slightly smaller deviations (17 $\%)$, when compared to the HS model which treats the London clay as a homogeneous soil (27\%). This especially concerns settlements on the ground surface.

Furthermore, it was observed that the heterogeneous HS model describes somewhat better the consolidation settlement of soil for the case of the tunnel situated in deeper clay layers, as compared to the anisotropic Wongsaroj model. Generally, the analyzed deviation of calculated consolidation settlements from measured ones shows that predictions of time periods of displacements in soil are similar and acceptable from the engineering point of view for all models under study, and that deviations are relatively low, i.e. that calculations are in good agreement with field observations. It was established by parametric analysis [14] that the change in consolidation settlements is mostly influenced by drainage conditions in tunnel lining, which confirms the results obtained by Wongsaroj $[4,5]$.

\subsection{Numerical simulation of foundation pit excavation in Zagreb clay}

A similar analysis for two HS models, one that takes into account the heterogeneity of clay, and the other that treats the Zagreb clay as a homogeneous soil, was conducted for the case of foundation pit excavation at the Ban Centre locality in Zagreb. Calculations for horizontal displacement of diaphragm are presented for typical cross-sections along the south-side and east-side of the diaphragm, and these values are then compared with in-situ measurements in inclinometers I-2 and $\mathrm{I}-5$ (Figures 10 and 11).

It can be seen from comparison between average deviations of calculated horizontal displacements of the diaphragm and measured horizontal displacements of the diaphragm (southside and east-side contour), for the isotropic heterogeneous HS model (19\%) and isotropic homogeneous HS model (56 $\%)$, that much smaller deviations of model results from insitu measurements are obtained using procedures that take into account natural heterogeneity of stiff Zagreb clays (heterogeneous HS model), when compared to the model that does not use these procedures (homogeneous HS model). A detailed account of analyses and results for deviation of 

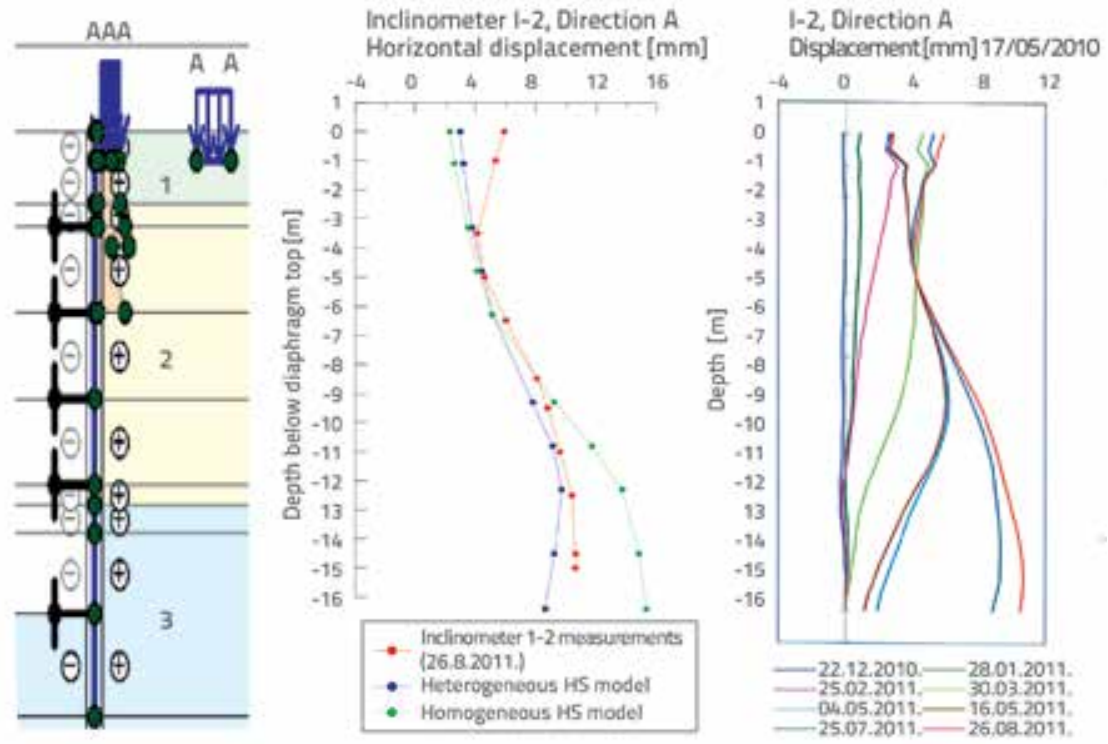

Figure 10. Comparison of calculated and measured horizontal displacements of the southside diaphragm contour for excavation until the final level of $103.2 \mathrm{~m}$ asl $(16.8$ $\mathrm{m}$ below the ground surface): a) numerical model in Plaxis 2D (1 - light green normally overconsolidated clay, 2 - light brown - gravel, 3 - light blue - Zagreb clay); b) calculated displacement results c) measurement results obtained at inclinometer I-2 [18]
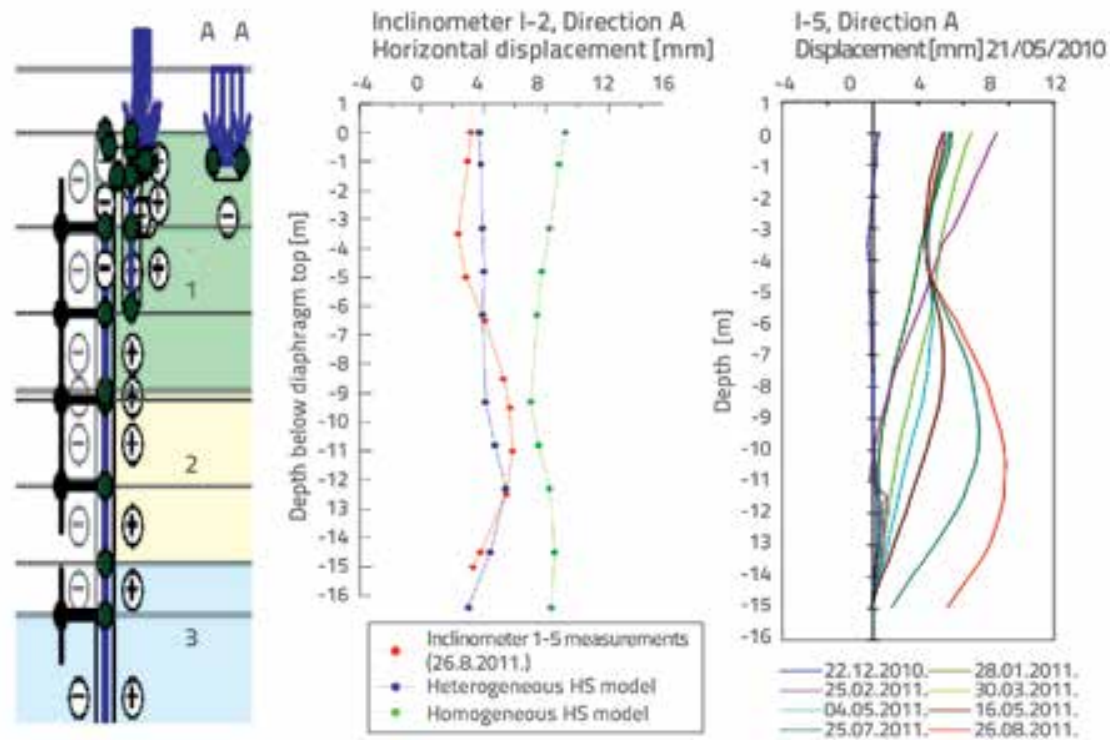

Figure 11. Comparison of calculated and measured horizontal displacements of the east-side diaphragm contour for excavation until the final level of $103.2 \mathrm{~m}$ asl $(16.8 \mathrm{~m}$ below the ground surface): a) numerical model in Plaxis 2D (1 - light green - normally overconsolidated clay, 2 - light brown - gravel, 3 - light blue - Zagreb clay); b) calculated displacement results c) measurement results obtained at inclinometer I-5 [18]

calculations from in-situ measurements is given in [14].

Results have confirmed observations made in case of London clay: the use of HS soil model together with appropriate procedures for the determination of soil parameters, which take into account natural heterogeneity of stiff clays, can result in much better prediction of displacement of protective structure (diaphragm) due to excavation of foundation pit in soil.

\section{Conclusion}

The reinterpretation of available data on mechanical properties of London clay was made for the case of construction of two metro tunnel tubes at Jubilee Line Extension (JLE) in the St. James's Park zone in London. Taking into account the bedding of London clay, and the data on the change in natural moisture content along the depth, correlations were established between parameters of the constitutive soil model HS, which is often used for numerical simulation of geotechnical structures in soil. The application of these correlations on measured moisture values at the St. James's Park locality has resulted in different computational soil stiffness for each sub-layer of London clay. Numerical simulation results for the case of tunnel construction in London have revealed that the use of HS model, which takes into account the heterogeneity of soil stiffness values between different sub-layers, shows a much smaller deviation of calculated settlements from measured ones, when compared to the HS model in which London clay is treated as one homogeneous layer only.

The described procedure was confirmed in Zagreb clay for the case of foundation pit excavation at the Ban Centre locality in Zagreb. Analysis results for the south-side and east-side contours of the foundation pit revealed that the isotropic heterogeneous HS model, which takes into account the heterogeneity of stiffness between various Zagreb clay sub-layers, describes much better the behaviour of the protective structure (diaphragm) than the HS model in which the heterogeneity in the thick clay layer is not taken into account. Analytical results obtained on isotropic HS models were also compared with Wongsaroj's studies on an anisotropic model. The results have revealed that the influence of soil heterogeneity on the prediction of soil settlement is as 
important as the influence of soil stiffness anisotropy. Thus, the results that are acceptable for engineering practice can be obtained, even if anisotropy is neglected.

This confirms that technically acceptable predictions of immediate and consolidation settlements of soil due to construction of tunnels and foundation pits can be obtained by taking into account the natural heterogeneity of soil, which can be observed through heterogeneity of natural moisture of clay.

\section{REFERENCES}

[1] Terzaghi, K.: Opening discussion and closing address, Proceedings of 1st International Conference of Soil Mechanics, Harvard University, 1936.

[2] Lambe, T.W.: Predictions in soil engineering, Geotechnique 23, No.2, pp. 149-202, 1973.

[3] Simons, N.E., Menzies, B.K.: A Short Course in foundation engineering, Thomas Telford, 224p, 2000.

[4] Wongsaroj, J.: Three-dimensional finite element analysis of short and long ground response to open-face tunnelling in stiff clay, PhD thesis, University of Cambridge, 2005.

[5] Wongsaroj, J., Soga, K., Mair, R.J.: Modelling of long-term ground response to tunnelling under St. James's Park, London, Geotechnique, Vol.57, No.1, pp. 75-90, 2007.

[6] Hashiguchi, K., Ueno, M.: Elastoplastic constitutive law of granular material: constitutive equations for soils, Proceedings of 9th International Conference of Soil Mechanics and Foundation Engineering, Tokyo, Special Session 9, pp. 73-82, 1977.

[7] King, C.: The stratigraphy of the London Basin and associated deposits, Tertiary Research Special Paper, Vol.6, Backhuys, 1981.

[8] Standing, J.R., Burland, J.B.: Report on ground characterisation to explain tunnelling volume losses in the Westminster area, Internal report, Imperial College, University of London, 1999.

[9] Hight, D.W., McMillan, F., Powell, J.J.M., Jardine, R.J., Allenou, C.P.: Some characteristic of London Clay, Characterisation and Engineering Properties of Natural Soils - Tan et. al. (eds), Swets \& Zeitlinger, 2003.

[10] Schanz, T.: Zur Modellierung des mechanicsen Verhaltens von Reibungsmaterialien, Mitteilungen, Heft 45, Institut of Geotechnical Engineering, University of Stuttgart, Stuttgart, 1998.

[11] Brinkgreve, R.B.J., Vermeer, P.A.: Plaxis Finite Element Code for Soil and Rock Analysis, Balkema, 2001.

[12] Brinkgreve, R.B.J., Broere, W., Vermeer, P.A.: Plaxis 3D Tunnel V2, Delft University of Technology \& Plaxis B.V., The Netherlands, 2004.

[13] Gasparre, A.: Advance laboratory characterisation of London Clay, PhD thesis, Imperial College of London, 2005.

[14] Milaković, D.: Trenutačna i konsolidacijska slijeganja tla izazvana bušenjem tunela u krutim glinama, Doktorska disertacija, Građevinski fakultet Sveučilišta u Zagrebu, 2012.

[15] Yimsiri, S.: Pre-failure deformation characteristic of soils: Anisotropy and soil fabric, PhD thesis, University of Cambridge, 2001

[16] Standing, J.R., Burland, J.B.: Unexpected tunnelling volume loss in Westminster area, London. Geotechnique, Vol.56, No.1, pp. 11-26, 2006.

[17] Nyren, R.J.: Field measurements above twin tun nels in London Clay, PhD thesis, Imperial College, University of London, UK, 1998.

[18] Kavur, B., Savi, R.: Stambeno-poslovni objekt Ban Centar Izvještaj o mjerenju (završni), Institut IGH d.d., kolovoz 2011. 